\title{
Impact of Teaching Methods on Learner Preferences and Knowledge Gained When Informing Adults About Gene Editing
}

\author{
R. Theil ${ }^{1}$, A. Bowling ${ }^{2}$, J. Rumble 3 , B. McFadden ${ }^{3}$, K. Stofer ${ }^{4}$, K. Folta $^{5}$
}

\begin{abstract}
Consumer acceptance of gene-editing technologies is a major hurdle to technology use, and opposition to gene-editing technologies may accompany a lack of knowledge by consumers. The purpose of this mixed-method study was to describe which method of instruction, behaviorism or constructivism, consumers preferred when learning about gene-editing and determine which method resulted in the highest amount of knowledge gained. Data were collected from eight focus groups across the country through a multiple-choice knowledge scale and open-ended questions. The qualitative results indicated that the participants preferred the behaviorism style over constructivist style due to the clarity of materials, the efficiency of time, and individual work. A large portion of participants felt the exposure to both teaching methods gave them more knowledge, that the information was interesting, and that they wanted more information. The quantitative results indicated that the behaviorist teaching method scores were significantly higher than the constructivist style of teaching. We recommend that practitioners align the appropriate teaching method with the amount of time allowed for the lesson, to use a variety of strategies when using behaviorist methods, and provide guidance and structure when using constructivist methods.
\end{abstract}

\section{Keywords}

Keyword: Andragogy, adult education, informal learning

1. Robby Thiel, Agriculture Educator, Riverside High School, 2096 County Road 24 S. Degraff, OH 43318, rthiel@ohiohipoint.com, (ID) https://orcid.org/0000-0002-3244-4971

2. Amanda Bowling, Assistant Professor, The Ohio State, 2120 Fyffe Road, Agricultural Administration 200F, Columbus, OH 43210, bowling.175@osu.edu, (D) https://orcid.org/0000-0002-2526-725X

3. Joy Rumble, Assistant Professor, The Ohio State University Dover Road, Halterman Hall 089C, Wooster, OH 44691, rumble.6@osu.edu, (D) https://orcid.org/0000-0001-8632-8688

4. Brandon McFadden, Associate Professor, University of Delaware, 513 S. College Ave. 224 Townsend Hall, Newark, DE 19716, foodecon@udel.edu, (iD) https://orcid.org/0000-0002-5993-3070

5. Kathryn Stofer, Research Associate Professor, University of Florida, PO Box 110540 University of Florida, Gainesville, FL 32611, stofer@ufl.edu, (D) https://orcid.org/0000-0002-3659-490X

6. Kevin Folta, Professor, University of Florida, PO Box 110690 Gainesville, FL 32611, kfolta@ufl.edu, 


\section{Introduction and Problem Statement}

Gene editing has been proposed as part of the agricultural technology and innovation needed to feed our ever-growing population (Godfray et al., 2010). Gene editing is a technology that allows scientists to make changes to DNA including removing, adding, or replacing DNA (National Human Genome Research Institute, 2021). However, consumer acceptance of science and gene-editing technology is essential (Baker \& Burnham, 2001). While an extensive body of literature exists regarding the often-negative perceptions of genetically modified food (Yang \& Hobbs, 2020), less research has examined perceptions of gene editing in the food and agricultural context. Yang and Hobbs (2020) found that cultural values, along with attitudes toward science and technology, and risk/benefit attitudes toward gene editing all impacted acceptance and that opposing attitudes appeared to be weaker than attitudes of opposition regarding genetic modification. McCaughey et al. (2019) found that adults from 125 different countries did not necessarily distrust gene editing for human applications, but they needed a better understanding of the technology to form their opinions. Although early research seems to suggest less opposition to gene edited foods (Food and Drug Administration, 2020) as compared to genetically modified foods (Food and Drug Administration, 2020), the opportunity exists to better understand how to inform consumers, who are likely three to four generations removed from production agriculture (Roberts et al., 2016).

Andragogy, a blend of different educational theories that address adults' learning preferences and the differences in how knowledge is assimilated (Knowles, 1980), provides a lens through which to understand how adult education impacts knowledge of gene editing in agricultural applications such as crop and livestock modifications. By understanding the influence of adult education on knowledge of gene editing, we can further understand how future acceptance or opposition to the technology in agriculture may evolve with different instructional methods. The purpose of this study was to describe consumer instructional preferences between behaviorism and constructivism and how these different methods impacted knowledge.

\section{Theoretical and Conceptual Framework}

We utilized the learning theories of behaviorism and constructivism to frame to the experimental design, qualitative focus group questions, development of lesson plans, and teaching strategies utilized. Additionally, andragogy was used to frame the experience of the adult learners, the development of lesson plans, and served as a lens during data analysis. Andragogy is the teaching framework that is the basis for adult learning that differentiates itself from pedagogy or youth learning (Knowles et al., 1998). The underpinnings for andragogy lie in Knowles' et al. (1998) six assumptions of adult learning: (a) Learner's need to know, (b) Selfconcept of the learner, (c) Prior experience of the learner, (d) Readiness to learn, (e) Orientation to learning, and ( $f$ ) Motivation to learn. Andragogy also asserts that adults typically have more, and varied learning experiences compared to children. Educators should focus on adding to adults' baseline knowledge (Knowles, 1980). Adults experience learning when new meaning impacts an earlier experience or opinion, causing them to reinterpret the old 
experience (Gutierrez et al., 2010). The andragogy assumptions further state that educators should ensure a learner-centered approach and should take on more of the role of a facilitator rather than a teacher (Cochran \& Brown, 2016). This approach allows the learner to take ownership of the material, allowing the adult to be oriented to learning.

Behaviorism, commonly associated with lecture-based teaching, is the oldest and most classic learning theory (Autrey, 1999; Bandura, 1977; Skinner, 1938; Skinner, 1963). Behaviorism is a teacher-centered approach, also known as a direct instruction approach. Contradictory to the assumptions of andragogy, behaviorism considers that learners are a blank slate and can learn information from expert knowledge and sources (Hallman et al., 2003). During direct instruction, learners receive knowledge from an expert in an explicit manner then engage with the provided material, and the educator assesses if learning has occurred before moving onto the next material. This method is commonly considered very intensive and places a great deal of emphasis on explicit instruction, the expertise level of the educator, and the delivery, practice, and review of material (Autrey, 1999).

Contrary to behaviorism, constructivism is a learner-centered approach that engages the learner in developing knowledge (Bezuidenhout et al., 2004; Piaget, 1970; Simpson, 2002). This method is learner-centered, as it allows learners to create their ideas and thoughts through self-discovery. In this method, teachers help facilitate knowledge growth instead of directly giving it (Fosnot, 1996) and knowledge is constructed by peers, superiors, and others (Smith, 2015).

Experts have debated about whether behaviorism or constructivism is most effective (Kirschner et al., 2006). Studies focused on behaviorism have shown that learners who receive worked examples rather than unaided forms of problems had a higher transfer of knowledge (Atkinson et al., 2000; Clark \& Estes, 1998, 1999). Further studies have shown that direct instruction allows for substantial knowledge transfer (Klahr \& Nigam, 2004; Schwartz \& Bransford, 1998), a more significant improvement in conceptual knowledge, and the ability to understand future material (Rittle-Johnson et al., 2001). When comparing behaviorism and constructivism, longterm effects of learner recall have shown little difference quantitatively, but qualitatively there have been differences in learning from those that had an active engagement with the materials (Semb \& Ellis, 1994). Additionally, constructivist approaches have found to be effective when teaching science concepts (Adak, 2017), and behaviorism does not allow for active learning processes often used when teaching science (Agarkar \& Brock, 2017).

\section{Purpose}

This mixed-method study describes which method of instruction, constructivist or behaviorist, was preferred and resulted in highest knowledge gained among adults learning about gene editing. The following research objectives and questions guided the inquiry:

1. Describe participants' knowledge after participating in a single instruction method. 
2. Determine if a difference exists between knowledge gained after participating in a singular instruction.

3. Describe the participants' knowledge after participating in both instruction methods.

4. Identify whether the order of participation in the instruction method impacted knowledge.

5. What method of instruction do adult learners perceive to be more beneficial to learning information?

6. What degree of alignment does the learner's teaching methods preference have with their amount of knowledge gained from that teaching method?

\section{Methods}

\section{Design and Sampling}

We used a mixed-method concurrent design collecting data at the same time and location (Creswell, 2014; Tashakkori \& Teddlie, 2010). A mixed methods approach allowed us to capture both knowledge gained and participant perceptions. We collected data during the winter and spring of 2020 from participants in eight different in-person focus group discussions, in four different locations (Dallas, TX; Columbus, OH; Philadelphia, PA, San Francisco, CA). We selected these locations to represent the United States' diverse regions and temperaments of individuals (Rentfrow et al., 2013).

We utilized a third-party organization to identify potential participants using the organization's voluntary log for each city, and we then nonrandomly selected participants. A recruitment script qualified participants based on age, gender, income, employment, cell phone ownership, confirmation of state residency, and trust in science. We were not interested in subcategories of people based on demographic characteristics and thus recruited for a mix of ages, genders, income, and employment comparable to the U.S. adult population (Krueger \& Casey, 2014). Additionally, the participants had to own a smart phone to participate in the designed focus group activity and score at least a 21 out of $35(60 \%)$ on the trust in science questions (National Science Board, 2018). Potential participants scoring lower than 21 were excluded from the research to eliminate strong negative biases against science from the discussion. We made this decision following a recommendation from our panel of experts, which included individuals with expertise in science communication, genetic modification technologies, behavioral economics, and andragogy.

We recruited 10-12 participants in each location as recommended by Krueger and Casey (2014), however some of the recruited participants did not attend the focus groups. A total of 65 individuals participated in the focus groups, with 4-9 individuals participating in each group. The participants were purposively placed into one of two experimental groups by focus group to keep their focus group intact, with group one receiving a behaviorist teaching method first and group two receiving a constructivist teaching method first. After each teaching method, all participants received a knowledge test (see Figure 1). 


\section{Figure 1}

Experimental Design

Group 1 (Philadelphia 1, Dallas 1, Columbus 1, San Francisco 1): $\quad$ X1 0 X2 0

Group 2 (Philadelphia 2, Dallas 2, Columbus 2, San Francisco 2): $\quad$ X2 0 X1 0

Note. $X 1=$ Behaviorist Method, $X 2=$ Constructivist Method, $O=$ Knowledge Test

\section{Experimental Treatments}

One researcher who was an agricultural education Master's student taught both the behaviorist and constructivist treatment in person. The behaviorist teaching method introduced the subjects to gene editing through two brief videos and a researcher developed article. One of the videos was from DuPont and timestamps shown were 0:33 - 2:33 (Pioneer Seeds United States, 2017). The other video was from Best Food Facts, a non-industry internet blogger, and timestamps shown were 0:00 - 3:02 (Best Food Facts, 2018). Participants were given shortened versions of each video and were not aware of the source from the DuPont video due to time constraints. After group discussion, the knowledge test was administered. The constructivist teaching method started with randomly dividing the participants into three groups. Each group was assigned one of three gene editing topics (comparison to other technologies such as genetic modification, uses, or regulation). Participants researched their given topic through provided researcher developed articles or self-discovery using their mobile devices. They were asked to share what they learned with the group. After group discussion, the knowledge test was administered. Each teaching method treatment lasted 30 minutes to allow time for other components of the research.

\section{Quantitative Methods and Analysis}

We used quasi-experimental design to understand which treatment resulted in more knowledge gained (Creswell, 2014). We collected knowledge data through a 10-question, multiple-choice test we developed, confirmed by our panel of experts. A pilot test $(n=9)$ was conducted to estimate test/re-test reliability through bivariate correlates. Question three was reworded as a result of the pilot $(n=9, \rho=-.109, p=.780)$. Question four $(n=64, \rho=.241, p=$ $0.55)$ and question six $(n=62, \rho=.223, p=.085)$ did not meet reliability standards but were left in as this study was exploratory. Caution should be used in interpreting the knowledge test. Data for objectives one and three were analyzed using descriptive statistics and objectives two and four were analyzed using an independent sample $t$-test to compare the group scores.

\section{Qualitative Methods and Analysis}

A collective case study was chosen and bound to emphasize the selection of individuals with neutral or positive trust in science (Miles \& Huberman, 1994; Stake, 1995; Yin, 2003). In person focus groups were facilitated by the same researcher who taught the lesson and included questions focused on participants' preferences in teaching methods and lesson components. Example focus group questions included: which activity did you prefer and why, what could have been changed about either method that would have helped you engage and learn from the material, and how has learning about this information changed your thoughts and feelings about gene editing. The focus group audio, video, and transcription served as the primary data 
sources. Participant notes, annotations, flip charts, and focus group field notes served as ancillary data sources. Method triangulation was achieved through the multiple data sources (Carter et al., 2014). All data sources were coded and then categorical aggregation was used to identify emergent themes and pseudonyms were assigned (Creswell, 2013). Passages from the collected data were determined if they were meaningful and then given a code that summarized the passage. Then, similar passages were clustered together for themes, and consistent re-working of the themes was accomplished, as no themes were pre-determined. The data were then separated into the teaching method order that was received to analyze if differences occurred in their viewpoint based on the order of teaching methods. The data were developed using naturalistic generalizations, to understand the data and transfer to other cases (Creswell, 2013). Trustworthiness was upheld through moderator guides, member checking through summaries at the end of the focus groups, peer debriefs through monthly research team members, and thick, rich descriptions (Lincoln \& Guba, 1985). The data were analyzed by an agricultural education master's student who grew up on a grain farm in the Midwest. The themes were confirmed by two faculty members one specializing in agricultural education and the other in agricultural communication, both with ties to production agriculture.

\section{Convergent Data Analysis}

We analyzed the quantitative and qualitative data separately for each independent question and objective (Creswell \& Clark, 2017). The qualitative and quantitative data were then triangulated to address the convergent question.

\section{Findings}

The study's findings should be interpreted with caution due to the limitations including nonrandom and purposive sampling, limited instruction time, repeated measures, and incentivization of participants (\$100 in OH, PA, TX, \$125 in CA due to higher cost of living). Funding was provided through a United Stated Department of Agriculture (USDA) Agricultural and Food Research Initiative (AFRI) grant.

\section{Quantitative Findings}

Objective 1: Describe participants' knowledge after participating in a singular instruction method.

The participants completed the knowledge test after the first instructional method. The participants' ( $n=30$ ) average score of correct answers after receiving the behaviorist method was 5.20 out of a possible 10 questions $(S D=1.97)$. The participants $(n=34)$ average score of correct answers after the constructivist methods was 3.65 out of a possible 10 questions ( $S D=$ 2.20).

Objective 2: Determine if a difference exists between knowledge gained after participating in a singular instruction.

Participants of the behaviorist lesson on average scored higher $(M=5.20, S D=1.97)$ than those who participated in the constructivist lesson $(M=3.65, S D=2.20)$. The mean difference of 1.55 
was statistically significant $(p=.004)$ and represented a medium effect size $(t(62)=2.96, p=$ $.004, d=0.74)$.

\section{Objective 3: Describe the participants' knowledge after participating in both instruction methods.}

The total participants' $(n=64)$ average score after engaging in both instructional methods was 5.76 out of a possible 10 questions (SD $=2.12)$. Group 1 participants' $(n=30)$ average score after the behaviorist-constructivist methods was $5.37(S D=2.14)$. Group 2 participants' $(n=34)$ average score after the constructivist-behaviorist methods was 5.58 (SD $=2.12$ ). Number of correct answers by treatment group for each survey question, at both measures, can be found in Table 1.

\section{Table 1}

\section{Number of correct answers for each knowledge test question}

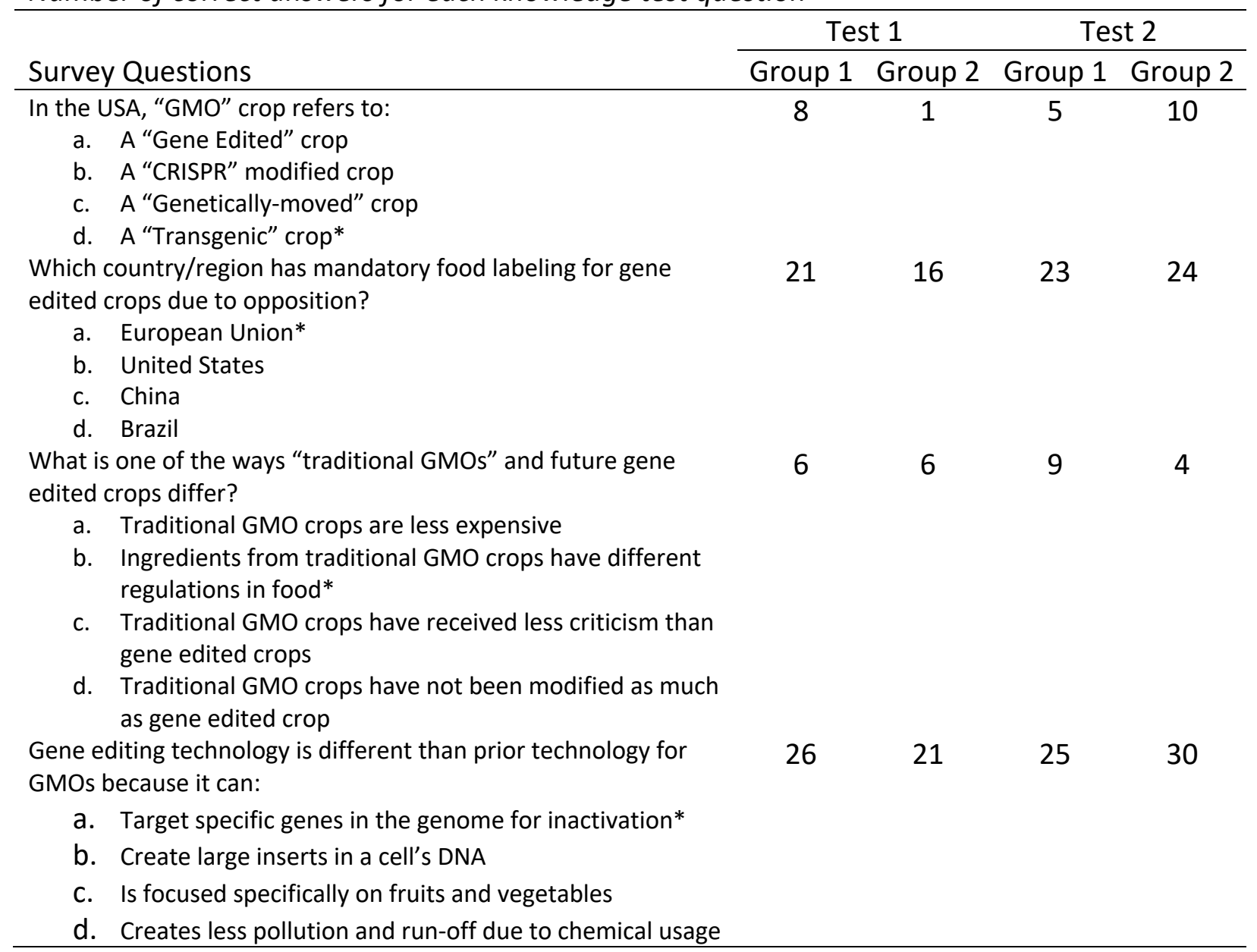




\section{Objective 4: Identify whether the order of participation in the instruction method impacted knowledge.}

On average, participants who started with the constructivist method (Group 2) scored higher on the second knowledge test $(M=5.76, S D=2.12)$ than those who started with the behaviorist teaching method $(M=5.37, S D=2.13)$. However, the mean difference of -0.39 was not significant $t_{62}=-0.75, p=.458$, and represented a negligible effect size $(t(62)=-0.75, p=.458, d$ $=-.19)$.

\section{Qualitative Findings}

Qualitative data were analyzed to determine what method of instruction the adult learners perceived to be more beneficial to learning information on gene editing. From the analysis, themes emerged within both the behaviorist and constructivist instructional methods and no themes emerged regarding preferences toward the order to which participants engaged in the two teaching methods. For the behaviorist method, four themes emerged and included: materials provided, individualized work, predetermined learner preferences for multimodal materials, and time constraints of lesson. For the constructivist method two themes emerged and included: collaborative learning and unlimited resources with limited time.

\section{Participants' Preference of Instruction Method: Behaviorism}

Materials Provided. A majority of participants noted that inside of the behaviorist instructional method, the clear and concise information that was presented helped them learn more and thus influenced their preference. The information presented to the participants allowed the participants to compare terminology, as Yander stated, "I wanted a copy of [the materials] because I thought it was very explicit. It was really clear you could find the difference between GMO and genetic altering." The materials that were provided to the participants also helped guide them in learning information. As Yvonne stated, it helped them learn about gene editing, "because there was more information, and we weren't looking out, because we were guided." Nicky also said, "I liked it because it was more concise, and it gave you the information. It gave you a place to go." The participants also sensed that information from the behaviorist method would give them more direction in terms of questions that would be on the test.

Individualized Work. A majority of participants also preferred the behaviorist teaching method due to being able to do individual work. Some participants felt more comfortable working alone and able to focus more. Frank stated, "I'm not distracted by the other people, and I can get to what I want to find out." Additionally, many participants discussed that they appreciated having time to individually read and reflect prior to engaging in a large group discussion. Other participants liked the individual work because of not being forced to share and present information. Otis was the first participant to answer the question and mentioned he preferred the method due to, "Reading and watching the videos, because I'm not much into giving presentations." Others wrote down that they also did not enjoy presenting or that they just wanted to sit and learn. The feeling of displeasure was expanded with Fran feeling uneasy about presenting information they were not an expert on by saying, "It's a concept and a subject that I really have very little information on, so it wasn't comfortable for me talking 
about it." The participant was observed as being disgruntled that they had to present information to others.

Predetermined Learner Preferences. A majority of participants also stated they appreciated being able to see and hear the information reinforced in the materials. Some participants came into the focus group with the idea that they had a certain preference for learning using multi-modal materials, potentially biasing them toward certain materials. For instance, Wayne said, "The best part about the second one [behaviorist method], I thought, was the visuals. Yeah. Yeah. I'm a visual person, so I preferred that one." Others in the same group also commented and nodded their heads when they heard this. The idea of being able to see the materials was also shared across other focus groups. Kriss also stated that, "I thought the videos were very helpful just because of the visual." The same sentiment from Kriss was also shared by Cad, a participant from a separate group. Ike added, "The video and reading, that helped I feel like more because I think it was--I mean that's just how I learn. I'm a visual audio learner." The multi-modal presentation with ability to hear the information, in a video and not just through a picture, helped them learn information.

Time Constraints of Lesson. Lastly, many participants preferred the behaviorist method due to the amount of time given for each instructional method. The participants felt that given the short amount of time they had for each instructional method, the behaviorist method best used the time. The participants felt rushed in the constructivist teaching method, as Stan stated, "I preferred the first [behaviorist method], because I didn't feel the second one [constructivist method] really gave us enough time to do what we needed to do. We didn't have a chance really to communicate with each other afterwards or compare what we had read." The written responses were also flooded with short comments from just the simple comment of "TIME [sic]," to comments that participants wanted more time to understand in the constructivist method. Some participants felt rushed in the constructivist method, as Carlos commented that "Oh, man, but we didn't have time to prepare [our lesson in constructivist]." Overall, the limited amount of time overwhelmed the participants along with the added stress of sharing in the limited time in the behaviorist approach.

\section{Participants' Preference of Teaching Method: Constructivism}

Collaborative Learning. Just over half of the participants discussed that they enjoyed being able to work with others and collaborate to understand the material during the constructivist lesson. Participants were able to gather more information, as Izzy stated that, "You get different insights from your peers, and also, they can help you if you're just struggling with putting together an idea. They can help you to put closure on that." The participant was then nodding to their teammate during the activity and acknowledged that it was helpful to work with others from different backgrounds. This sentiment of working with people with different backgrounds was shared by Beth as they said, "It was more like people had different views on each thing, we got to read different things, and then come together as a whole and do it." 
These participants felt that working with others also gave them a greater sense of comfort as well. Zora commented, "You get a perspective of what everybody feels or [is] thinking, and it just makes you think even more so, I can't be all wrong, they were thinking the same thing I was thinking." This thought helped reinforce the participants' thoughts, and a sense of relief was felt by the participants as they laid back in their seats relaxed as they commented on this statement. The collaboration with others also allowed for having the participants to become more involved. Dave said, "watching a video, reading, is a passive act, acting with people is a much more active act. It's more involved." Dave was also an educator that shared that his students learn more from group work than writing and watching videos as well.

Unlimited Resources with Limited Time. The other major positive that a majority of participants felt through the constructivist method was the ability to have a vast number of resources at their disposal to understand gene editing. The participants were given three articles to start their research, but also were able to use their own technology to research on the given topic of gene editing. This was shared by Tim, who stated,

I think if we had time to really digest the articles and do research online, that we would have had a broader knowledge and been able to spend time discussing and having that other person's opinion, and we were just forced to rush through.

The entire section of constructivism was criticized by the limited time. Tim decided that he preferred the behaviorist option but would have chosen constructivist if time wasn't a factor. Right after the comments by Tim, Uma also stated, "I like the [behaviorist], but if we had unlimited time, I'd definitely like the [constructivist]... It's very overwhelming, and there's a lot to learn." The participant also noted that the constructivist made them feel overwhelmed, but it was not negative. The sense of vast number of materials was also stated by Dan with, "If we had an hour to do that method, I think that would have been extremely helpful. More knowledgeable." Dan could be seen tapping the table and seeming a bit anxious when commenting on the overwhelming amount of material.

\section{Convergent Findings}

The convergent question sought to understand the alignment of learners' perceived instructional method preference with their knowledge gained. From the qualitative data, a majority of the participants discussed their preference for the behaviorist teaching method over the constructivist method. Their preference was predicated on the materials that were provided to them. The amount of time allowed in both methods, the visual and auditory information, feeling of more knowledge gained, and being able to work individually were all components of why the participants enjoyed the behaviorist method. Some participants did prefer the constructivist method, but the time that was allowed for them in this setting was a factor for not choosing this method. The preference for the behaviorist teaching method aligned with the knowledge gained, as a statistically significant difference was seen between the behaviorist and constructivist lesson with participants scoring higher after engaging in the behaviorist lesson.

When comparing the second knowledge test, participants who received a constructivistbehaviorist method scored $M=5.76$, while the behaviorist-constructivist method scored $M=$ 
5.37. The independent samples t-test was not statistically significant, and the order of methods did not appear to impact the number of answers that were answered correctly. Additionally, participants had limited to no conversation that order of the methods impacted the amount of knowledge gained and no qualitative themes emerged regarding the order of the methods.

\section{Conclusions, Discussion, and Recommendations}

From the quantitative findings, we concluded that participants displayed a statistically significant higher score on the knowledge test following the completion of the behaviorist lesson as compared to the constructivist lesson which aligns with previous findings (Klahr \& Nigam, 2004; Schwartz \& Bransford, 1998). We also concluded that after receiving both types of teaching methods, no statistical difference occurred in knowledge test scores.

From the qualitative findings, participants overwhelmingly preferred the behaviorist teaching method to that of the constructivist teaching method, which contradicts the assumptions of Andragogy (Knowles, 1980). The participants cited the easily accessible materials, connection of behaviorism with the short time that was given for the lesson, the use of visually to connect to the content being taught, and individualized work. While participants preferred the behaviorist method the most, some benefits of the constructivist approach emerged. Participants appreciated the collaborative nature of the constructivist lesson and the availability of unlimited resources if given the proper amount of time to explore them.

Additionally, there was an alignment with the participants' preferred instructional methods and the amount of knowledge gained. This finding aligns with prior literature which has shown greater knowledge when learning preference is met (Wilson et al., 2016). Participants overwhelmingly favored behaviorist methods in the qualitative portion of the study and the alignment of preference and knowledge gained was further supported as participants scored higher on the knowledge test following the behaviorist methods as compared to the constructivist method. Based on this alignment, a behaviorist method could be more beneficial to share factual knowledge with adults than a constructivist teaching method when solely using one method and in limited time. However, a behaviorist teaching method may not be desirable for all consumers. Learners, in particular adult learners, want to feel that they are in control of their learning (Knowles, 1980), as adults are self-directed human beings that have shifted from dependent learners to independent learners. However, it is important to note that the behaviorist approaches used during this study were not solely lecture-based and had multiple activities, which may be reason that participants did not point out that they were not in control of their learning. Previous research supports that learners scored higher on an end of course assessment when exposed to a variety of teaching methods as compared to lecture alone (Johnson \& Mighten, 2005).

Recommendations can be made for practitioners who are teaching adults about gene editing in agricultural applications such as school-based agriculture teachers, extension educators, and academic and/or industry-based researchers. Whether it is the school-based agriculture teacher or extension educator educating their community members or researchers educating 
consumers about scientific findings, recommendations can be made when using constructivist and behaviorist teaching methods. First, practitioners should consider the amount of time dedicated to the lesson. Longer lessons would be more suitable for the exploration necessary for constructivist methods. Whereas behaviorist methods are more appropriate for shorter lessons and short non-formal learning engagements. For constructivist methods it is recommended that sufficient time be provided to allow learners time to explore the numerous resources available and reflect (Cooperstein \& Kocevar-Weidinger, 2004). If time is limited, the educator should consider restricting the resources learners use or provide guidance on potential resources to use. Second, educators should provide clear directions and structure to the learners, especially if the learners have no prior experience with the topic. When using behaviorist teaching methods educators should use multiple approaches beyond just direct instruction such as questioning, drills, guided practice, and consistent review. Finally, learning materials should have both visual and auditory components to engage a variety of learner preferences.

Recommendations for future research can be made to further investigate and enhance educating adults about complex scientific topics, such as gene editing. First, this study could be replicated by increasing the instructional time for each teaching method and increasing the sample size. Next, a study should integrate both behaviorist and constructivist instructional methods in a single learning setting to then be compared to the use of each method separately. Lastly, research should explore how gene editing curriculum and communication tools could engage adult learnings in more meaningful ways to move beyond rote memorization to constructing knowledge which could influence their scientific perceptions.

\section{Acknowledgements}

This work was supported by the USDA National Institute of Food and Agriculture [2018-6702329795].

\section{References}

Adak, S. (2017). Effectiveness of constructivist approach on academic achievement in science at secondary level. Educational Research and Reviews, 12(22), 1074-1079. https://doi.org/10.5897/ERR2017.3298

Agarkar, S., \& Brock, R. (2017). Learning theories in science education. In K. S. Taber \& B. Akpan (Eds.), Science Education (pp. 91-103). Sense Publishers. https://link.springer.com/content/pdf/10.1007/978-94-6300-749-8 7.pdf 
Atkinson, R. K., Derry, S. J., Renkl, A., \& Wortham, D. (2000). Learning from examples: Instructional principles from the worked examples research. Review of Educational Research, 70(2), 181-214.

https://journals.sagepub.com/doi/pdf/10.3102/00346543070002181?casa token=i6nsp NnEoB4AAAAA:UmSH4nG086o1F71kj9Li2EBDwvAKQkPQfanINS9n6PvPCnnrFw6gwgVHr W8DDdOTMX1LR-87kiRv

Autrey, J. H. (1999). Effects of direct instruction and precision teaching on achievement and persistence of adult learners [Unpublished doctoral dissertation]. Wayne State University.

Baker, G. A., \& Burnham, T. A. (2001). Consumer response to genetically modified foods: Market segment analysis and implications for producers and policy makers. Journal of Agricultural and Resource Economics, 26(2), 387-403. https://www.jstor.org/stable/40987116?seq=1\#metadata info tab contents

Bandura, A. (1977). Social learning theory. Prentice Hall.

Bezuidenhout, J., Van der Westhuizen, D., \& De Beer, K. J. (2004). Andragogy: A theoretical overview on learning theories that impact on benchmarking blended learning at the Central University of Technology. Interim: Interdisciplinary Journal, 3(2), 1-27.

Best Food Facts. (2018, May 7). How Can CRISPR Improve Food? [Video file]. You Tube. https://www.youtube.com/watch?v=tyNynnKECBs.

Carter, N., Bryant-Lukosius, D., DiCenso, A., Blythe, J., \& Neville, A. J. (2014). The use of triangulation in qualitative research. Oncology Nursing Forum, 41(5), 545-547. https://doi.org/10.1188/14.ONF.545-547

Clark, R. E., \& Estes, F. (1998). Technology or craft: What are we doing? Educational Technology, 38(5), 5-11. : https://www.jstor.org/stable/44428476

Clark, R. E., \& Estes, F. (1999). The development of authentic educational technologies. Educational Technology, 39(2), 5-16. https://www.jstor.org/stable/44428515

Cochran, C., \& Brown, S. (2016). Andragogy and the adult learner. In K. A. Flores, K. D. Kirstein, C. E. Schieber, \& S. G. Olswang (Eds.), Supporting the success of adult and online students (pp. 73-84). CreateSpace. http://repository.cityu.edu/bitstream/handle/20.500.11803/594/Chap7Supporting.pdf? sequence $=2$ 
Cooperstein, S. E., \& Kocevar-Weidinger, E. (2004). Beyond active learning: A constructivist approach to learning. Reference Services Review, 32(2), 141-148.

https://doi.org/10.1108/00907320410537658

Creswell, J. W. (2013). Quantitative inquiry and research design: Choosing among five approaches (3rd ed.). SAGE.

Creswell, J. W. (2014). A concise introduction to mixed methods research. SAGE.

Creswell, J. W., \& Clark, V. L. P. (2017). Designing and conducting mixed methods research. SAGE.

Food and Drug Administration (2020). Types of genetic modification methods for crops. https://www.fda.gov/food/agricultural-biotechnology/types-genetic-modificationmethods-crops

Fosnot, C. (1996). Constructivism: Theory perspectives and practice. Teachers College Press.

Godfray, H. C. J., Beddington, J. R., Crute, I. R., Haddad, L., Lawrence, D., Muir, J. F., Pretty, J., Robinson, S., Thomas, S. M., \& Toulmin, C. (2010). Food security: The challenge of feeding 9 billion people. Science, 327(5967), 812-818.

https://doi.org/10.1126/science.1185383

Gutierrez, C. C., Baralt, S. T., \& Shuck, M. B. (2010). The integrated process of engagement in adult learning. In M. S. Plakhotnik, S. M. Nielsen, \& D. M. Pane (Eds.), Proceedings of the ninth annual college of education \& GSN research conference (pp. 33-39). Florida International University.

Hallman, W. K., Hebden, W. C., Aquino, H. L., Cuite, C. L., \& Lang, J. T. (2003). Public perceptions of genetically modified foods: A national study of American knowledge and opinion. Food Policy Institute, Cook College, Rutgers University. https://doi.org/10.7282/T37M0B7R

Johnson, J., \& Mighten, A. (2005). A comparison of teaching strategies: Lecture notes combined with structured group discussion versus lecture only. Journal of Nursing Education, 44(7), 319 - 322. https://doi.org/10.3928/01484834-20050701-06

Kirschner, P. A., Sweller, J., \& Clark, R. E. (2006). Why minimal guidance during instruction does not work: An analysis of the failure of constructivist, discovery, problem-based, experiential, and inquiry-based teaching. Educational psychologist, 41(2), 75-86. https://www.asec.purdue.edu/LCT/HBCU/documents/Analysis of the Failure of Disco very $\mathrm{PBL}$ Experiential Inquiry Learning.pdf 
Klahr, D., \& Nigam, M. (2004). The equivalence of learning paths in early science instruction: Effects of direct instruction and discovery learning. Psychological Science, 15(10), 661667. https://doi.org/10.1111/j.0956-7976.2004.00737.x

Knowles, M. S. (1980). The modern practice of adult education: From pedagogy to andragogy: Revised and updates. Adult Education.

Knowles, M., Holton, E., \& Swanson, R. A. (1998). The adult learner: The definitive classic in adult education and human resource management. Gulf Publishing.

Krueger, R. A., \& Casey, M. A. (2014). Focus groups: A practical guide for applied research. SAGE.

Lincoln, Y. S., \& Guba, E. G. (1985). Establishing trustworthiness. Naturalistic inquiry, 289(331), 289-327. http://dx.doi.org/10.1016/0147-1767/85)90062-8

McCaughey, T., Budden, D. M., Sanfilippo, P. G., Gooden, G. E. C., Fan, L., Fenwick, E., Rees, G., MacGregor, C., Si, L., Chen, C., Liang, H. H., Pébay, A., Baldwin, T., \& Hewitt, A. W. (2019). A need for better understanding is the major determinant for public perceptions of human gene editing. Human Gene Therapy, 30(1) $251-256$, https://doi.org/10.1089/hum.2018.033

Miles, M. B., \& Huberman, A. (1994). Qualitative data analysis: An expanded sourcebook. SAGE.

National Human Genome Research Institute. (2021). What is genome editing? https://www.genome.gov/about-genomics/policy-issues/what-is-Genome-Editing

National Science Board. (2018). Science and technology: Public attitudes and understanding. https://www.nsf.gov/statistics/2018/nsb20181/assets/404/science-and-technologypublic-attitudes-and-understanding.pdf

Piaget, J. (1970). Piaget's theory. In P. Mussen (Ed.), Carmichael's manual of child psychology (3rd ed., Vol. 1, pp. 703-732). Wiley.

Pioneer Seeds United Stated. (2017, June 6). CRISPR-Cas for Healthy Seed Development [Video file]. You Tube. https://www.youtube.com/watch?v=KUApt4RIU1M.

Rentfrow, P. J., Gosling, S. D., Jokela, M., Stillwell, D. J., Kosinski, M., \& Potter, J. (2013). Divided we stand: Three psychological regions of the United States and their political, economic, social, and health correlates. Journal of Personality and Social Psychology, 105(6), 9961009. http://dx.doi.org/10.1037/a0034434 
Rittle-Johnson, B., Siegler, R. S., \& Alibali, M. W. (2001). Developing conceptual understanding and procedural skill in mathematics: An iterative process. Journal of Educational Psychology, 93(2), 346-362. https://doi.org/10.1037//0022-0663.93.2.346

Roberts, T. G., Harder, A., \& Brashears, M. T. (Eds). (2016). American Association for Agricultural Education national research agenda: 2016-2020. Department of Agricultural Education and Communication.

Schwartz, D. L., \& Bransford, J. D. (1998). A time for telling. Cognition and instruction, 16(4), 475-522.

Semb, G. B., \& Ellis, J. A. (1994). Knowledge taught in school: What is remembered? Review of Educational Research, 64(2), 253-286. https://doi.org/10.3102/00346543064002253

Skinner, B. F. (1938). The behavior of organisms: An experimental analysis. Appleton-Century.

Skinner, B. F. (1963). Behaviorism at fifty. Science, 140(3570), 951-958. https://www.jstor.org/stable/1711326

Simpson, T. L. (2002). Dare I oppose constructivist theory? The Educational Forum, 66(4), 347354. https://doi.org/10.1080/00131720208984854

Smith, K. (2015). Constructivist design theory. The University of Memphis. http://www.kevindsmith.org/uploads/1/1/2/4/11249861/idt7074-constructivist-designtheory-kevin-smith.pdf

Stake, R. E. (1995). The art of case study research. SAGE.

Tashakkori, A., \& Teddlie, C. (Eds.). (2010). Sage handbook of mixed methods in social \& behavioral research. SAGE.

Wilson, A. B., Taylor, M. A., Klein, B. A., Sugrue, M. K., Whipple, E. C., \& Brokaw, J. J. (2016). Meta-analysis and review of learner performance and preference: Virtual versus optical microscopy. Medical Education, 50(4), 428-440. https://doi.org/10.1111/medu.12944

Yang, Y., \& Hobbs, J. E. (2020). Supporters or opponents: Will cultural values shape consumer acceptance of gene editing? Journal of Food Products Marketing, 26(1), 17-37. https://doi.org/10.1080/10454446.2020.1715316

Yin, R. K. (2003). Case study research: Design and methods (3rd ed.). SAGE.

(C) 2022 by authors. This article is an open access article distributed under the terms and conditions of the Creative Commons Attribution license (http://creativecommons.org/licenses/by/4.0/). 